\title{
金属種を複合したポリピロール錯体担持炭素粒子の酸素還元触媒活性
}

\author{
湯浅 真 $\mathrm{a}, \mathrm{b}$, 小柳津研一 ${ }^{\mathrm{b}}$, 村田 英則 $\mathrm{a}, \mathrm{b}$, 田中 健 ${ }^{\mathrm{a}}$, 山本 昌邦 $\mathrm{a}$, 佐々木真一 ${ }^{\mathrm{a}}$ \\ a 東京理科大学理工学部（广 278-8510 野田市山崎 2641） \\ b 東京理科大学総合研究機構（解162-8610 東京都新宿区神楽坂 1-3)
}

\section{Electrocatalytic Activities for the Reduction of Oxygen of Carbon Particles Modified with Polypyrrole Including Various Metal Ions as Electrocatalytic Sites}

\author{
Makoto Yuasa, Kenichi Oyaizu, Hidenori Murata, Ken Tanaka, Masakuni Yamamoto, and Shinichi Sasaki \\ a Department of Pure and Applied Chemistry, Faculty of Science and Technology, Tokyo University of Science \\ (2641 Yamazaki, Noda-shi, Chiba 278-8510, Japan) \\ ${ }^{b}$ Research Institute for Science and Technology, Tokyo University of Science (1-3 Kagurazaka, Shinjuku-ku, \\ Tokyo 162-8510, Japan)
}

Received May 14, 2007 ; Accepted July 11, 2007

\begin{abstract}
We reported that carbon black modified with cobalt and various transition metal ions (M) incorporated in a polypyrrole film $(\mathrm{Co}+\mathrm{MPPy} / \mathrm{C})$ were good electrocatalysts for the reduction of oxygen $\left(\mathrm{O}_{2}\right)$. After heat treatment of the catalysts at 600 to $650^{\circ} \mathrm{C}$ under argon atmosphere, which were prepared using with iron and iridium ions as $\mathrm{M}$, the resulted catalysts gave rise to the reduction of $\mathrm{O}_{2}$ at a remarkably positive potential $\left(E_{\mathrm{p}}>0.40 \mathrm{~V}\right.$ vs SCE). Rotating ring disk voltammetry (RRDV) revealed that $\mathrm{Co}+\mathrm{IrPPy} / \mathrm{C}$ reduced $\mathrm{O}_{2}$ completely with four electrons $\left(n_{\mathrm{av}}=4.0\right)$. X-ray photoelectron spectroscopy and X-ray diffraction indicated that the cobalt and $\mathrm{M}$ ions were coordinated with nitrogen as the donor atoms and the active sites were maintained even after the heat treatment under argon atmosphere without aggregation of metals and formation of alloys.
\end{abstract}

Key Words : Electrocatalyst, Polypyrrole Film, RRDV, Heat Treatment

\section{1 緒 言}

固体高分子形燃料電池のカソード触媒として用いられてい る白金担持炭素粒子 $(\mathrm{Pt} / \mathrm{C})$ は，稀少資源であることから コスト高という問題を抱えている．そのため，白金の担体上 への高分散担持や遷移金属との合金化などが検討・評価され るとともに，新材料の開発が切望されている ${ }^{1-3)}$. 代替材料 の研究として, 大環状金属錯体であるコバルトポルフィリン $(\mathrm{CoP})$ が，酸素 $\left(\mathrm{O}_{2}\right)$ から水までの 4 電子還元を効果的に 触媒することが報告されており ${ }^{4-19)}$ ，これ以来， $\mathrm{O}_{2}$ 配位の動 的過程や中間体の構造解析など基礎的な研究も含め, 現在で も幅広く検討されている ${ }^{20)}$.これまでに著者らは， CoPの活 性中心であるコバルトー窒素 $\left(\mathrm{Co}_{\mathrm{O}} \mathrm{N}_{4}\right)$ 構造に着目した分子 設計と，燃料電池の実用レベルで問題になる触媒の安定性お よび耐久性を考慮して, 流動床電解重合により炭素粒子表面 に導電性高分子のポリピロールを修飾し，コバルトイオンと の不均一系反応から Co- $\mathrm{N}_{4}$ 構造を高分散に担持させた触媒を 合成した ${ }^{21)}$ 。このような触媒では, 炭素粒子表面において活 性点が原子レベルで形成されているために，金属原子当たり の触媒活性は既存の $\mathrm{Pt} / \mathrm{C}$ に比べ高くなる. さらに, 得られ た高分子錯体を不活性ガス雲囲気下において熱处理した触媒
が, $\mathrm{O}_{2}$ 還元反応に対して高い選択度を示し, 各種 $\mathrm{X}$ 線分光 法による解析から Co- $\mathrm{N}_{4}$ 構造に基づく触媒特性であることを 見出している ${ }^{21)}$. 本報では, コバルトポリピロール担持炭素 粒子 $(\mathrm{CoPPy} / \mathrm{C})$ に多種の遷移金属㧍よび貴金属を導入さ せることで，添加した金属種の複合効果（ $\pi$ 電子の逆供与効 果など）に基づく多電子移動系の構築から， $\mathrm{O}_{2}$ 還元反応に 対する選択度の向上を試みた。この際に複合化させる金属イ オンの導入比を詳細に精査し, 最適化された導入比で調製し た触媒に熱処理を施すことで, 活性中心である $\mathrm{Co}_{\mathrm{O}} \mathrm{N}_{4}$ 構造の 高密度化に基づく飛躍的な触媒活性の向上を期待し, 新たな カソード触媒材料への展開を目的とした. 本報では特に, 鉄 とイリジウムを $\mathrm{CoPPy} / \mathrm{C}$ に導入した触媒について詳細に報 告する.

\section{1 触媒の調製}

2. 1.1 担体の前処理 円筒ろ紙に触媒担体である 炭素粒子 (Ketjen Black EC, BET 比表面積: $800 \mathrm{~m}^{2}$, 粒 径： $30 \mathrm{~nm}$, 三菱化学製) を約 $10 \mathrm{~g}$ 入れ, ソックスレー抽出 装置にセットした。洗浄溶媒 [ベンゼン（1 級，純度 $99.0 \%$ ， 
和光純薬工業製) /ヘキサン（特級，純度 $96.0 \%$, 和光純薬 工業製)，1/1（v/v)］を $300 \mathrm{~mL}$ 添加し，6時間洗浄した。 その後, $120{ }^{\circ} \mathrm{C}$ で減圧乾燥を 3 時間行った。使用前に瑪瑙乳 鉢で完全に粉砕したものを触媒調製に用いた。

\subsection{2 ピロールの流動床電解重合 2.1.1 で得} られた炭素粒子 $3.0 \mathrm{~g}$ をノマーであるピロール $5.6 \mathrm{~mL}$ (特 級，純度 $98.0 \%$, Aldrich 製）と支持電解質として過塩素酸 アンモニウム $\left(\mathrm{NH}_{4} \mathrm{ClO}_{4}\right)(0.1 \mathrm{~mol} / \mathrm{L})$ （特級，純度 $98.0 \%$ ， 和光純薬工業製）を含む電解液 [水/メ夕ノール（1 級，純 度 $99.5 \%$ ，和光純薬工業製)，4/1 (v/v)］ $250 \mathrm{~mL}$ に分散さ せ，この溶液を流動床電解装置（Fig. 1）の作用電極室に投 入した。その後，各種電極 [作用極：白金線 $(\varphi 1 \mathrm{~mm}$, 全 長 $30 \mathrm{~cm}$ )，対極：ステンレス板（電極面積 $35 \mathrm{~cm}^{2}$ ), 参照 極： $\mathrm{Ag} / \mathrm{AgCl}]$ を電解セルに挿入させ，一定かくはん， $\mathrm{Ar}$ 雲囲気下において，作用極にピロールの酸化に相当する電位 （1.8 V vs Ag/ AgCl）を印加することで，炭素粒子が白金線 に接触した瞬間だけ炭素粒子上にピロールの電解重合が進行 して，粒子表面にポリピロール膜が生成する．同時に作用極 上にもポリピロールが生成するが，導電性があるため次の炭 素粒子が衝突した時も作用極として働く.電解重合 $(45 \mathrm{~min})$ 後の炭素粒子を吸引ろ過によって捕集し, メタノールで繰り 返し洗浄後， $120^{\circ} \mathrm{C} ， 3$ 時間の条件で減圧乾燥を行った。乾 燥後, 瑪瑙乳鉢で粉砕することでポリピロール修飾炭素粒子 (PPy/C) を得た。

2. 1.3 配位子ポリピロールヘのコバルト（II）および 補助金属イオン（ $\mathbf{M}^{\mathrm{n}^{+}}$: 遷移金属）の導入 $\mathrm{PPy} / \mathrm{C} 1.5$ $\mathrm{g}$ を酢酸コバルト（II）四水和物 $3.0 \mathrm{~g}$ （特級，純度 $99.0 \%$, 和光純薬工業製）および各種遷移金属酢酸塩 $\left(\mathrm{M}^{\mathrm{n}+}=\mathrm{Mn}^{2+}\right.$,

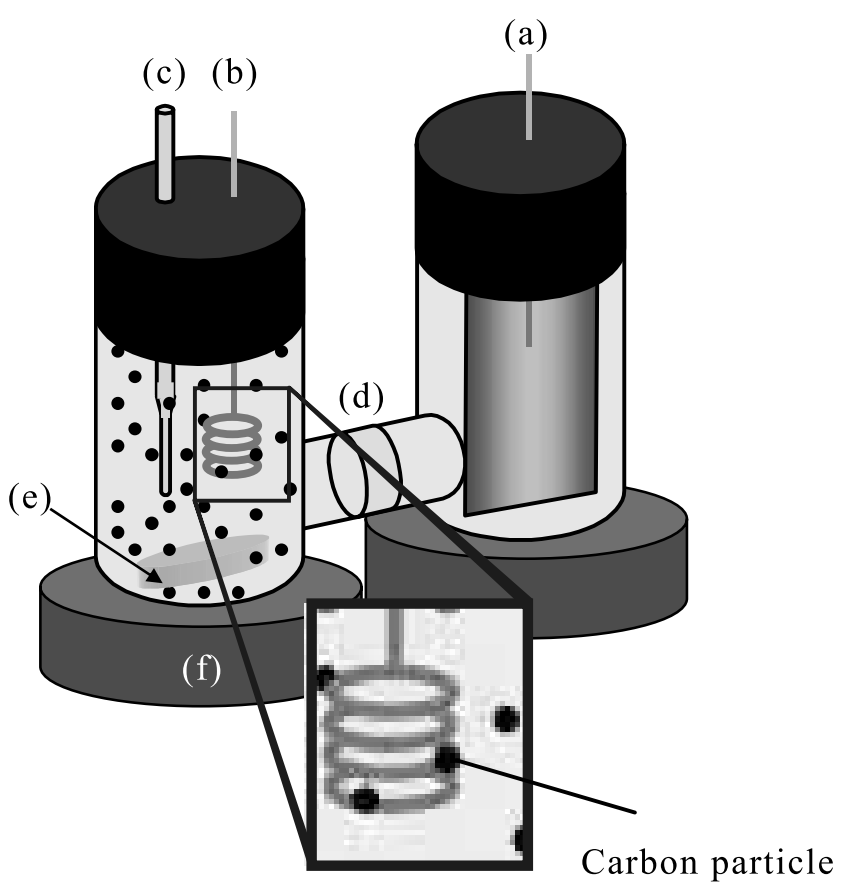

Fig. 1 Fluid-bed electrolysis apparatus. (a) stainless steel plate $\left(A=35 \mathrm{~cm}^{2}\right)$ as an auxiliary electrode, (b) coiled platinum wire $(\phi=1 \mathrm{~mm}, l=30 \mathrm{~cm})$ as a working electrode, (c) $\mathrm{Ag} / \mathrm{AgCl}$, (d) sintered glass separating membrane, (e) stirring bar, (f) magnetic stirrer.
$\mathrm{Mo}^{2+}, \mathrm{Fe}^{2+}, \mathrm{Ni}^{2+}$ および $\left.\mathrm{Cu}^{2+}\right)$ を所定の仕込み比で溶解させ たメタノール溶液中に分散させ，酸トラップ剤としてトリエ チルアミンを $1 \mathrm{~mL}$ (特級，純度 $99.0 \%$ ，和光純薬工業製） 添加した。この溶液を $\mathrm{Ar}$ 䨌囲気下で還流（65 ${ }^{\circ} \mathrm{C} ， 2$ 時間） し，室温まで放冷後，生成物を吸引ろ過によって捕集し，水 とメタノールで繰り返し洗浄後， $120^{\circ} \mathrm{C}, 3$ 時間の条件で減 圧乾燥をすることで多核金属ポリピロール修飾炭素粒子 $(\mathrm{Co}+\mathrm{MPPy} / \mathrm{C})$ を得た（同時法，以後，方法 1 とする).な お， $\mathrm{M}^{\mathrm{n}+} に \mathrm{Fe}^{2+}$ を用いた触媒では，金属種のポリピロールに 対する配位力を考慮して還流を二回に分けて行い，それぞれ $\mathrm{Co}^{2+}$ および $\mathrm{Fe}^{2+}$ を別々に錯形成させる方法も検討した（別 法，以後，方法 2 とする).

2. 1.4 配位子ポリピロールへのコバルト（II）および 補助金属イオン（ $\mathbf{M}^{\mathrm{n}+}$ : 貴金属）の導入 2.1 .3 項の 方法 1 を用いて， $\mathrm{M}^{\mathrm{n}+}$ として $\mathrm{Pt}^{2+}$ および $\mathrm{Rh}^{+}$を導入させた。 金属錯塩には，それぞれ $\left[\mathrm{Pt}\left(\mathrm{NH}_{3}\right)_{4}\right] \mathrm{Cl}_{2} \cdot \mathrm{xH}_{2} \mathrm{O}(\mathrm{x} \leqq 1$, 純 度 $98 \%$ ，SIGMA-Aldrich 製）および $\left[\mathrm{Rh}(\mathrm{CO})_{2} \mathrm{Cl}\right]_{2}$ （純度 97\%，SIGMA-Aldrich製）を用いた。また， $\mathrm{M}^{\mathrm{n}+} に \mathrm{Ir}^{+}$を用 いた触媒の錯形成反応は方法 2 により行い, 反応溶媒に 0 -キ シレン (特級，純度 $99.0 \%$ ，和光純薬工業製），金属錯塩と して $[\operatorname{Ir}(\mathrm{COD}) \mathrm{Cl}]_{2}$ （純度 $97 \% ，$ SIGMA-Aldrich 製）を用 いた.

2. 1 . 5 不活性ガス雲囲気下における熱処理 既 報 22,23) を参考に，最適担持比で調製された $\mathrm{Co}+\mathrm{MPPy} / \mathrm{C} の$ 熱処理を行った。熱処理の際, 触媒自体の酸化や，担体であ るカーボンブラックの燃焼などの様々な問題が予想されるた め，反応系をロータリーポンプで十分に排気し，不活性ガス の $\mathrm{Ar}$ を充てんさせる操作を繰り返すことで厳密な純 $\mathrm{Ar}$ 䨌囲 気下にしてから熱処理を行った。この時の熱処理温度（熱処 理時間： 2 時間および昇温速度： $5{ }^{\circ} \mathrm{C} / \mathrm{min}$ は固定）による 触媒活性への影響について詳細に検討し，処理条件と触媒活 性の関連を考察した。

\section{2 酸素還元触媒活性の評価}

合成した各種 Co+MPPy/C を Nafion ${ }^{\mathrm{TM}}$ 溶液 $250 \mu \mathrm{L} （ 5$ $\mathrm{wt} \%$ ，Aldrich 製）に分散させ，エッジ面パイロリティック グラファイト $(\mathrm{EPG})$ 電極（半径 $=0.3 \mathrm{~cm}$, 電極面積 $=0.28$ $\left.\mathrm{cm}^{2}\right)$ 上にキャストすることにより擬似 MEA を作製した。 作製した修飾電極を作用極として，対極に白金線，参照極に はSCEを用いた三電極法により電気化学測定 (CV, RDE 法 およびRRDE法）を行った。電解液には $1 \mathrm{M}$ 過塩素酸（純 度 $60 \%$, 和光純薬工業製)，電位掃引速度はCVにおいて 100 $\mathrm{mV} \mathrm{s}{ }^{-1}$, RDEおよびRRDE法では $5 \mathrm{mV} \mathrm{s}^{-1}$ 用いて 600〜 -200 mVの範囲で電流-電位曲線を測定した. CVの酸素飽 和下において得られる溶存酸素由来のピーク電位 $\left(E_{\mathrm{p}}\right)$ によ り, 触媒活性を評価した. 反応電子数 $(n)$ はRDEの各電極 回転速度（ $\omega=100,200,400,600$ および $900 \mathrm{rpm})$ における 限界拡散電流密度 $\left(i_{\mathrm{L}}\right)$ の逆数を縦軸に, $\omega$ の平方根の逆数 を横軸にとったKoutecky-Levich プロット［(1) 式］より得 られる直線の傾きから算出した。

$$
i_{\mathrm{L}}^{-1}=i_{\mathrm{K}}{ }^{-1}+\left(0.620 n F A D_{\mathrm{O}_{2}}{ }^{2 / 3} \omega^{1 / 2} v^{-1 / 6} C_{\mathrm{O}_{2}}{ }^{*}\right)^{-1}
$$

プロットの傾きは最小二乗法より算出し，溶存酸素の濃度 $\left(C_{\mathrm{O}_{2}}{ }^{*}=1.5 \times 10^{-3} \mathrm{~mol} / \mathrm{L}\right)$ と拡散係数 $\left(D_{\mathrm{O}_{2}}=2.0 \times 10^{-5} \mathrm{~cm}^{2} \mathrm{~s}^{-1}\right)$ および過塩素酸水溶液の動粘度 $\left(v=0.01 \mathrm{~cm}^{2} / \mathrm{s}\right)$ を使用した ${ }^{24)}$. 
さらに詳細な酸素還元機構の解析を目的として，RRDE法 を用いた．作用極に用いた白金リングーカーボンディスク電 極の捕捉率 $(N)$ は， $\left[\mathrm{Fe}(\mathrm{CN})_{6}\right]^{4-/}\left[\mathrm{Fe}(\mathrm{CN})_{6}\right]^{3-}$ を用いて実 測したところ， $\omega に$ 依らず一定の值 $(N=0.37)$ が得られた この值は, 流体力学の関係式を用いて導出された理論式より 算出した計算值 $(0.369)$ とほぼ一致している。

酸素還元反応では，酸素が式（2）および（3）のような 2 種類の電極反応を生起し, 副生物である過酸化水素が続けて 式（4）により電極反応を行う機構が想定される.

$$
\begin{gathered}
\text { Disk : } \mathrm{O}_{2}+4 \mathrm{e}^{-}+4 \mathrm{H}^{+} \rightarrow 2 \mathrm{H}_{2} \mathrm{O} \\
\mathrm{O}_{2}+2 \mathrm{e}^{-}+2 \mathrm{H}^{+} \rightarrow \mathrm{H}_{2} \mathrm{O}_{2} \\
\mathrm{H}_{2} \mathrm{O}_{2}+2 \mathrm{e}^{-}+2 \mathrm{H}^{+} \rightarrow 2 \mathrm{H}_{2} \mathrm{O}
\end{gathered}
$$$$
\text { Ring : } \mathrm{H}_{2} \mathrm{O}_{2} \rightarrow \mathrm{O}_{2}+2 \mathrm{e}^{-}+2 \mathrm{H}^{+}
$$

ここで式（1）の反応による電流が式（2）のx倍とすると， 得られる電流一電位曲線のディスクにおける限界拡散電流 $\left(i_{\mathrm{D}, \mathrm{L}}\right)$ とそのときのリング電流 $\left(i_{\mathrm{R}}\right)$ の比 $\left(N_{\mathrm{k}}\right)$ の逆数と $\omega$ の平方根には式（6）の関係がある.

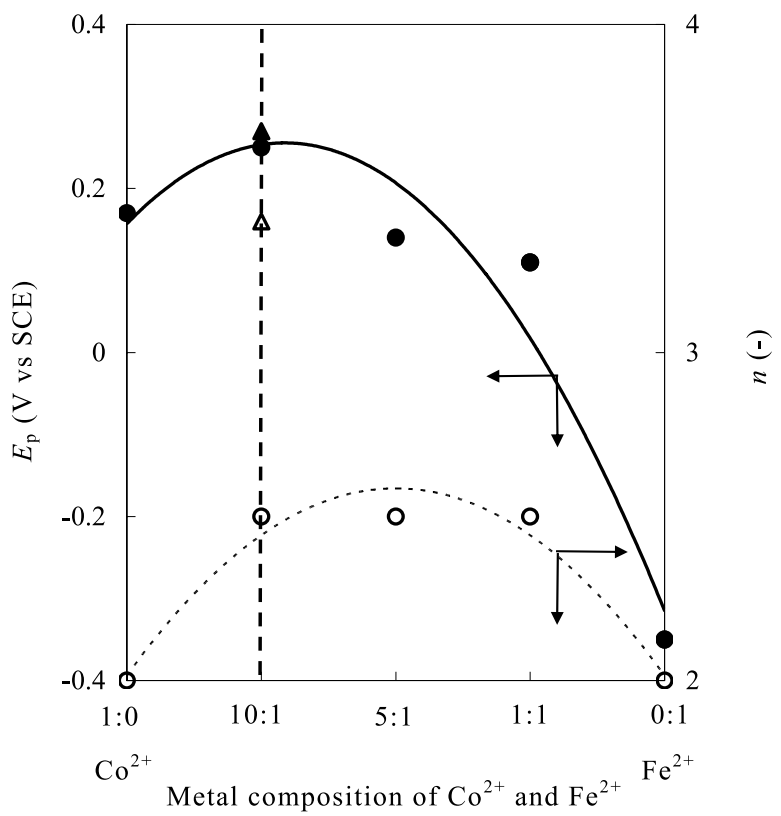

Fig. 2 Relationship between composition of metals $\left(\mathrm{Co}^{2+}\right.$ and $\mathrm{Fe}^{2+}$ ) incorporated into a PPy film and electrocatalytic activities of oxygen reduction. $\mathrm{Co}+\mathrm{FePPy} / \mathrm{C}$ prepared by method I ( $\bigcirc$ and $\bigcirc$ ) and by method II ( $\boldsymbol{\Delta}$ and $\triangle$ ).

Table 1 Structural parameters around cobalt atoms in $\mathrm{Co}+\mathrm{FePPy} / \mathrm{C}$ determined by EXAFS analysis.

\begin{tabular}{ccc}
\hline Abs.-Scat. & $\begin{array}{c}\text { Coordination } \\
\text { number }\end{array}$ & $\begin{array}{c}\text { Interatomic } \\
\text { distance }(\mathrm{nm})\end{array}$ \\
\hline Co-N & $4.5 \pm 0.5$ & $2.10 \pm 0.02$ \\
Co-Co & $1.7 \pm 1.0$ & $3.10 \pm 0.03$ \\
Co-Fe & $1.9 \pm 0.6$ & $3.13 \pm 0.03$ \\
Fe-N & $4.6 \pm 0.5$ & $2.11 \pm 0.02$ \\
Fe-Co & $1.9 \pm 0.4$ & $3.14 \pm 0.02$ \\
\hline
\end{tabular}

$$
i_{\mathrm{D}} / i_{\mathrm{R}}=N_{\mathrm{k}}^{-1}=(\mathrm{x}+1) / N+(\mathrm{x}+2) k /\left(N \omega^{1 / 2}\right)
$$

ここで速度定数 $(k)$ は $k=1.61 D^{-2 / 3} v^{1 / 6} k_{3}$ で表され，式 (4) の速度定数 $\left(k_{3}\right)$ が含まれている.

本評価では式（6）の関係を用いて，酸素還元反応機構を 検討すると同時に，得られる $N_{\mathrm{k}}$ と形状パラメータ $N$ を用い て過酸化水素発生率 $\left(\% \mathrm{H}_{2} \mathrm{O}_{2}\right)$ および反応電子数 $\left(n_{\mathrm{av}}\right)$ を 下記の式5）より算出し，酸素還元触媒能の評価指標とした. この際，上述の $N=0.37$ を用いて計算した.

$$
\begin{gathered}
\% \mathrm{H}_{2} \mathrm{O}_{2}=N_{\mathrm{k}} / N \times 100 \\
n_{\mathrm{av}}=4-2\left(N_{\mathrm{k}} / N\right)
\end{gathered}
$$

\section{3 触媒活性点のキャラクタリゼーション}

合成した Co+MPPy/Cについて，X線光電子分光法（XPS， AXIS-HI, MgK $\alpha$ ，島津製作所製）により担体表面に修飾さ
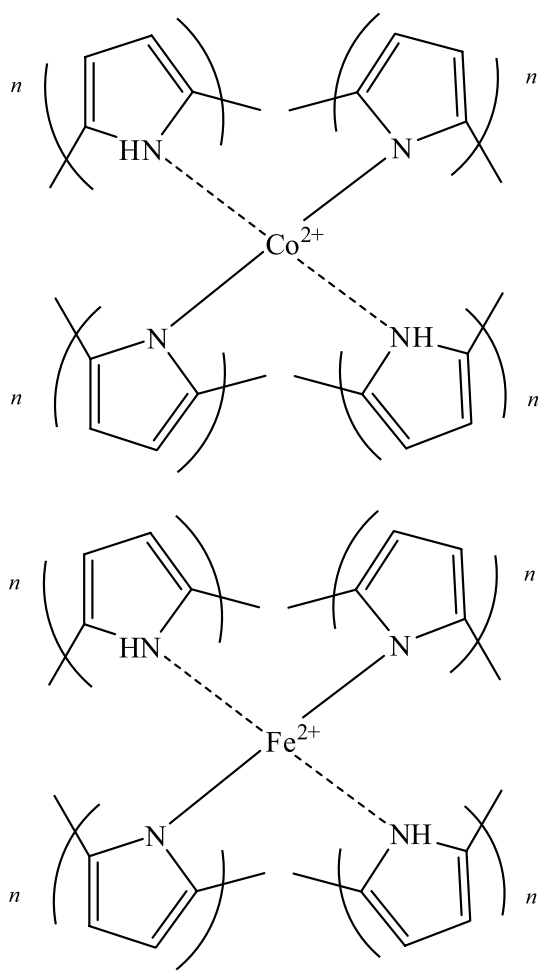

Fig. 3 Presumed Structure of $\mathrm{Co}+\mathrm{FePPy} / \mathrm{C}$.

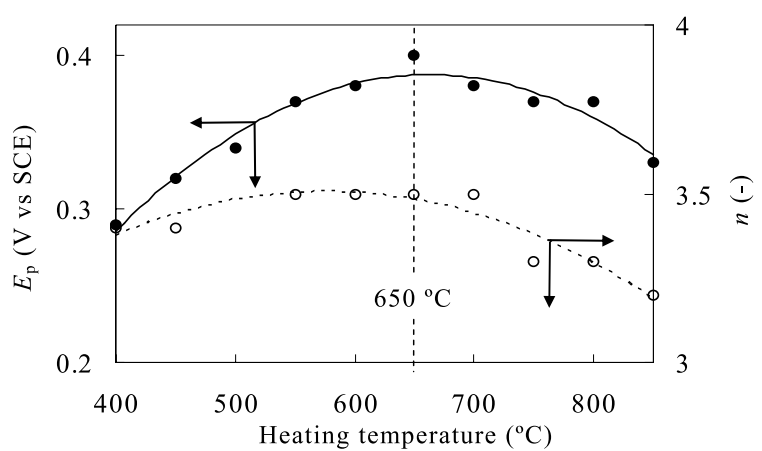

Fig. 4 Relationship between heating temperature and electrocatalytic activities of $\mathrm{Co}+\mathrm{FePPy} / \mathrm{C}$ for $\mathrm{O}_{2}$ reduction. 
(a)

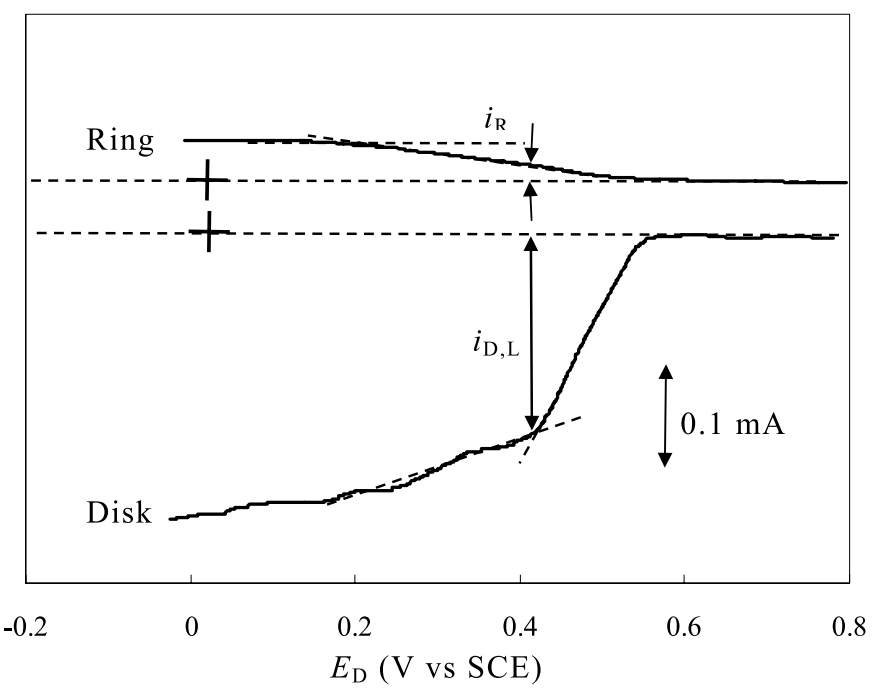

(b)

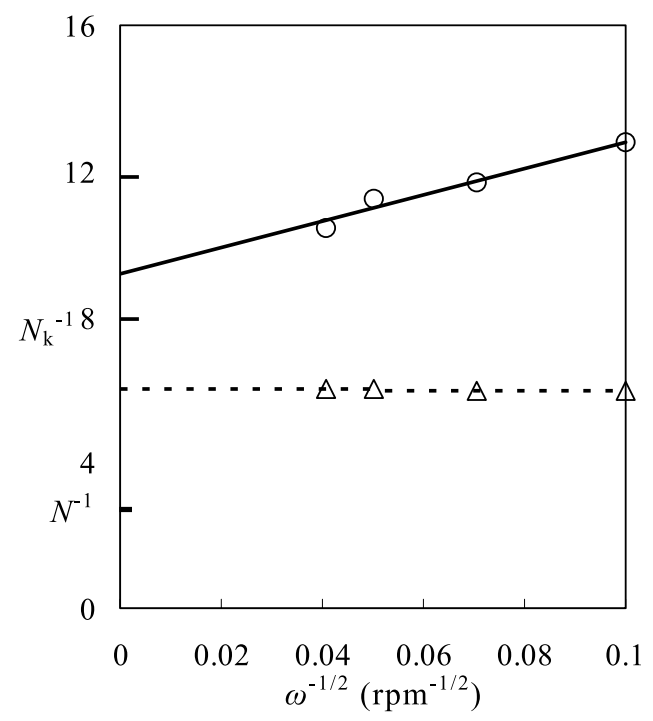

Fig. 5 (a) Current-potential curves for the reduction of $\mathrm{O}_{2}$ at a rotating platinum ring-graphite disk electrode (RRDE) modified with $\mathrm{Co}+\mathrm{FePPy} / \mathrm{C}$ after heat treatment at $650{ }^{\circ} \mathrm{C}$ under argon atmosphere in $\mathrm{O}_{2}$ saturated $1 \mathrm{M} \mathrm{HClO}_{4}$. The platinum ring was maintained at $1.2 \mathrm{~V}$ vs SCE. The collection efficiency of the RRDE was measured as 0.36 using the $\mathrm{Fe}(\mathrm{CN})^{3-4-}$ couple. $\omega=100 \mathrm{rpm}$. Scan rate $=5 \mathrm{mV}$ $\mathrm{s}^{-1}$. (b) $N_{\mathrm{k}}^{-1}$ vs $\omega^{-1 / 2}$ plots for the reduction of $\mathrm{O}_{2}$ at the RRDE in Fig. 4 (a) (solid line). The dotted line corresponded to the plots for the reduction of $\mathrm{O}_{2}$ at the electrode coated with $\mathrm{CoPPy} / \mathrm{C}$ after heat treatment at $600{ }^{\circ} \mathrm{C}$ under argon atmosphere. $\omega=100,200,400$, and $600 \mathrm{rpm}$.

せたポリピロールおよび金属イオンの確認を行った．導入し た各種金属の担持比をエネルギー分散型蛍光 X 線分析 (EDXRF, JSX-3200, RhKo，JEOL製）より決定した。Co- $\mathrm{N}_{4} お よ$ び $\mathrm{M}-\mathrm{N}_{4}$ 構造の確認のため, 広域 $\mathrm{X}$ 線吸収微細構造 (EXAFS, BL-12C, 高エネルギー加速器研究機構物質構造科 学所放射光研究施設）を用いた。測定は透過法で行い, $\mathrm{Co}$ のK吸収端スペクトルを用いて, UWXAFSにより解析し た. 熱処理に伴う金属凝集の有無を確認するために，粉末 $\mathrm{X}$

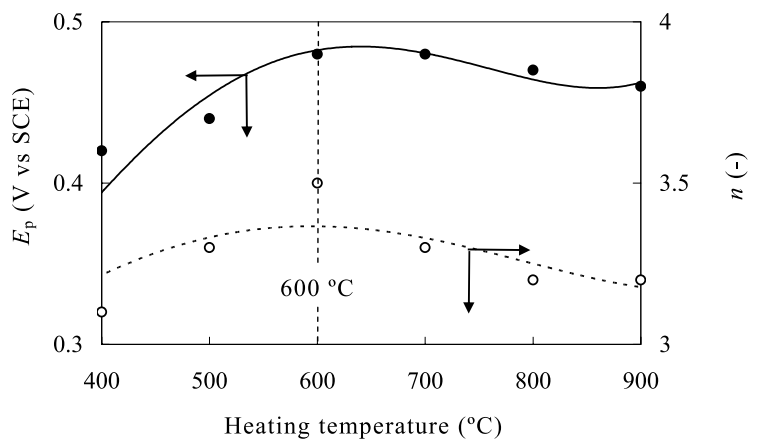

Fig. 6 Relationship between heating temperature and electrocatalytic activities of $\mathrm{Co}+\mathrm{IrPPy} / \mathrm{C}$ for $\mathrm{O}_{2}$ reduction.

(a)

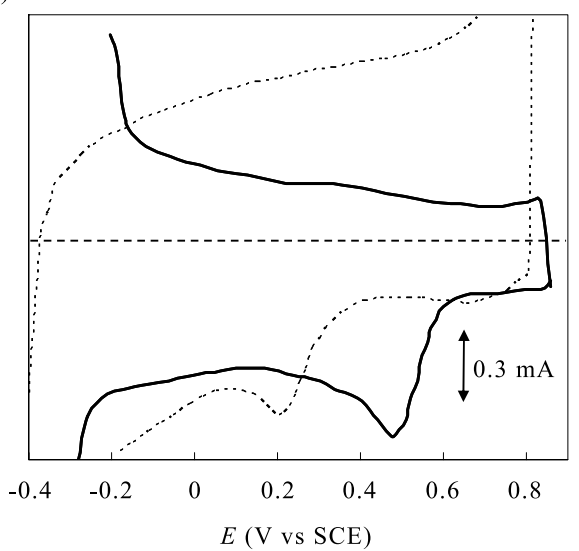

(b)

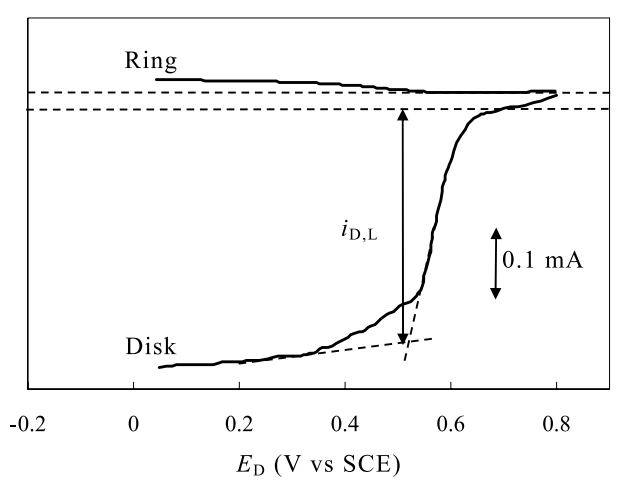

Fig. 7 (a) Cyclic voltammograms for the reduction of $\mathrm{O}_{2}$ at an EPG electrode modified with the pristine $\mathrm{Co}+\mathrm{IrPPy} / \mathrm{C}$ catalyst (dotted curve) and the catalyst after heat treatment at $600{ }^{\circ} \mathrm{C}$ under argon atmosphere (solid curve) in $\mathrm{O}_{2}$ saturated $1 \mathrm{M} \mathrm{HClO}_{4}$. Scan rate $=100 \mathrm{mV} \mathrm{s}^{-1}$. (b) Currentpotential curves for the reduction of $\mathrm{O}_{2}$ at a RRDE modified with $\mathrm{Co}+\mathrm{IrPPy} / \mathrm{C}$ after heat treatment at $600{ }^{\circ} \mathrm{C}$ under argon atmosphere in $\mathrm{O}_{2}$ saturated $1 \mathrm{M} \mathrm{HClO}_{4}$. The electrochemical condition was the same as Fig. 4 (a).

線回折（XRD, X’ pert pro, CuK $\alpha$, Philips 製）を用いた.

\section{3 結果および考察}

\section{3. $1 \operatorname{Co}+\mathrm{M}\left(\mathrm{M}=\mathrm{Fe}^{2+}\right) P P y / C$ の最適担持比の決定}

2.1 .3 項において, $\mathrm{M} に \mathrm{Mn}^{2+}, \mathrm{Mo}^{2+}, \mathrm{Fe}^{2+}, \mathrm{Ni}^{2+}$ および $\mathrm{Cu}^{2+}$ 第 2 金属として調製した触媒の CVを行ったところ， 
$\mathrm{M} に \mathrm{Fe}^{2+}$ を用いた $\mathrm{Co}+\mathrm{FePPy} / \mathrm{C}$ において，仕达み比がCo： $\mathrm{Fe}=10 ： 1.0$ のときに $E_{\mathrm{p}}$ が極大值を示した。このことより 本報では， $\mathrm{Fe}^{2+}$ の触媒特性について詳細に報告する。また Koutecky-Levich プロットから得られるnについても同様の 傾向となった（Fig. 2)。このときの金属種の担持比は, ED$\mathrm{XRF}$ から $\mathrm{Co}: \mathrm{Fe}=1.0 ： 1.3$ となった. 特に方法 2 で調製し た触媒では $E_{\mathrm{p}}$ が $0.27 \mathrm{~V}$ vs SCEまで向上した（Fig. 2のムプ ロット)。これは $\mathrm{CoPPy} / \mathrm{C} の$ 触媒活性 $\left(E_{\mathrm{p}}=0.23 \mathrm{~V}\right.$ vs SCE $)$ を上回り ${ }^{21)}$, 複合金属による効果が示唆された. 酸素還元能 が高いCo : $\mathrm{Fe}=1.0 ： 1.3$ の触媒を最適担持比と定義し, 以 後, 更なる性能向上を目的に熱処理条件を精査した.

\section{2 触媒活性点のキャラクタリゼーション}

3.1 項で決定した最適担持比 $(\mathrm{Co}: \mathrm{Fe}=1.0 ： 1.3)$ によ る触媒の炭素粒子表面に扔ける原子状態をXPSにより解析 した．高分子錯体を構成する $\mathrm{N}, \mathrm{Co}$ および $\mathrm{Fe}$ を想定して解 析したところ，各元素に対応するスペクトルを観測し，炭素 粒子上に触媒層が形成されていることを確認した。さらに, CoのK 吸収端 EXAFS スペクトル（Table 1）を用いた解析 から，金属一窒素間距離 $\left(R_{\mathrm{M}-\mathrm{N}}\right)$ は $2.10 \pm 0.02 \AA$ となり，こ れは既報 ${ }^{25)}$ にある CoPやフタロシアニンと同様の Co-N 結合 間の距離に相当する。また金属 - 窒素間の配位数が $4.5 \pm 0.5$ という結果を併せ，Co- $\mathrm{N}_{4}$ およびFe- $\mathrm{N}_{4}$ 構造（Fig. 3）が確認 された。ささらにコバルトー鉄原子間距離 $\left(R_{\mathrm{Co}-\mathrm{Fe}}\right)$ は $3.13 \pm$ $0.03 \AA$ 皇保っていることから, 酸素を架橋配位して $\mu$-パーオ キソ錯体の形成が可能なことが明らかとなり，酸素還元活性 の向上には Co- $\mathrm{N}_{4}$ 㧍よび $\mathrm{M}-\mathrm{N}_{4}$ 構造を有する高分子錯体が起 因していることが分かった.

\section{3 . 3 最適担持比で調製した $\mathrm{Co}+\mathrm{M}\left(\mathrm{M}=\mathrm{Fe}^{2+}\right)$ $\mathrm{PPy} / \mathrm{C}$ の熱処理条件の検討}

最適担持比において調製した $\mathrm{Co}+\mathrm{FePPy} / \mathrm{C}$ 各熱処理温 度 $\left(400 \sim 800{ }^{\circ} \mathrm{C}\right)$ において焼成したところ， $650{ }^{\circ} \mathrm{C}$ まで著し い $E_{\mathrm{p}}$ 㧍よび $n$ の増加（ $E_{\mathrm{p}}=0.40 \mathrm{~V}$ vs SCE, $n=3.5 ）$ し, $700{ }^{\circ} \mathrm{C}$ 以上の高温で処理した触媒では減少していく傾向が観 測された (Fig. 4). $650{ }^{\circ} \mathrm{C}$ で焼成した触媒の RRDE法よる電 流 - 電位曲線（Fig. 5 (a)） から $\% \mathrm{H}_{2} \mathrm{O}_{2}=21 \%, n_{\mathrm{av}}=3.6$ が 得られ, 酸素の 1 段階 4 電子還元機構が支配的に進行してい ることが明らかとなった．各 $\omega^{-1 / 2}$ に対して得られた $N_{\mathrm{k}}$ の逆 数をプロットした結果から，その挙動は右上がりの直線関係 （Fig. 5（b））を示し，CoPPy/C（Fig. 5（b）破線）とは異 なる酸素還元機構が見られた. CoPPy/Cにおいては, $N_{\mathrm{k}}{ }^{-1}$ が $\omega に$ 対して変化していないことから，式（4）の反応がほ とんど進行していないか，または非常に遅いことが分かる。 これに対して $\mathrm{Co}+\mathrm{FePPy} / \mathrm{C}$ で, 式（2）に加え式（4）の 反応が進行していることが推定される。これは複合化させた $\mathrm{Fe}^{2+}$ のフェントン機構に基づく過酸化水素の還元反応による ものと考えられる. 3.2 項のXPSスペクトルのケミカルシ フト（C 1s スペクトルの $284.5 \mathrm{eV}$ を基準とした）が金属の $\mathrm{Fe}\left(706.8 \mathrm{eV}^{26)}\right)$ に比べ高エネルギー側へのシフトが観測さ れたこと，また XRD パターンから $6500^{\circ} \mathrm{C}$ ま゙の触媒におい ては金属種による回折が見られないこと，さらに触媒活性評 価における $\mathrm{pH}$ 条件 $(\mathrm{pH} \approx 0)$ に対し, $\mathrm{Fe}$ の Pourbaix ダイ アグラムを併せると，ポリピロール中の Fe は二価の錯体と して機能していることが支持される。

\section{3. $4 \mathrm{Co}+\mathrm{M}\left(\mathrm{M}=\mathrm{Pt}^{2+}, \mathrm{Ir}^{+}\right.$および $\left.\mathrm{Rh}^{+}\right) \mathrm{PPy} / \mathrm{C}$ の最適 担持比の決定}

2.1.4 項において, 各種貴金属塩 $\left(\mathrm{M}=\mathrm{Pt}^{2+}, \mathrm{Ir}^{+}\right.$および $\left.\mathrm{Rh}^{+}\right)$の仕込み量を調整することでポリピロールへの金属導 入比を変化させたところ, Mに $\mathrm{Ir}^{+} を$ 用いた系において $\mathrm{CV}$ の溶存酸素還元に由来するピーク電流が $E_{\mathrm{p}}=0.22 \mathrm{~V}$ vs SCE

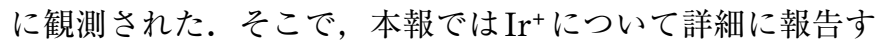
る. $\mathrm{Co}^{2+}$ 全く添加しない $\mathrm{IrPPy} / \mathrm{C}$ の場合, その酸素還元活 性は CoPPy/Cに比べ低く $\left(E_{\mathrm{p}}=0.01 \mathrm{~V}\right.$ vs SCE $), C o$ イオン と共存させることで複合効果が見られた。既存の Irポルフィ リン錯体における酸素還元反応では, $\mathrm{Ir}^{2+}$ の原子価状態にお いて酸素が中心金属にサイドーオン型の配位をするため, 一 分子で酸素の 4 電子還元反応を生起することが報告されてお り ${ }^{27,28)}$ ，その $\mathrm{Ir}^{2+/+}$ のレドックス電位 ${ }^{27)}\left(E^{0^{\prime}}\left(\operatorname{Ir}^{2+++}\right)=0.14 \mathrm{~V}\right.$ vs SCE）を考慮すると $\mathrm{IrPPy} / \mathrm{C} て ゙ は ~ \mathrm{Ir}^{+}$の状態が想定され， 高い酸素還元活性を示さなかったと考える. ED-XRFより最 適担持比は $\mathrm{Co}_{0}: \mathrm{Ir}=1.0 ： 1.0$ と決定した。

\section{5 最適担持比で調製した $\mathrm{Co}+\mathrm{M}\left(\mathrm{M}=\mathrm{Ir}^{+}\right) \mathrm{PPy} / \mathrm{C} の$ 熱処理条件の検討}

3.4 項で決定した最適担持比による Co+IrPPy/Cの熱処 理温度による触媒特性の変化を検討した。 その結果, 熱処理 温度 $600{ }^{\circ} \mathrm{C}$ で焼成したときに酸素還元活性が極大值を示し， それ以上の温度では活性の低下を招いている（Fig. 6)。 $600{ }^{\circ} \mathrm{C}$ で熱処理後の Co+IrPPy/C 修飾させた EPG 電極によ る溶存酸素還元に由来する $E_{\mathrm{p}}$ は, 顕著に貴側へシフトして いる（Fig. 7 (a))。ささらにRRDEによる電流一電位曲線 (Fig. $7(\mathrm{~b}))$ から, 半波電位 $\left(E_{1 / 2}=0.57 \mathrm{~V}\right.$ vs SCE) にお いて $n_{\mathrm{av}}=4.0$ が得られ, 酸素から水への 4 電子還元触媒とし て機能することが分かった。貴金属にロジウムを用いた $\mathrm{Co}+\mathrm{RhPPy} / \mathrm{C}$ では熱处理後の XRD から金属結晶の生成が確 認されたが， $600{ }^{\circ} \mathrm{C}$ までの昇温に対してCo, Ir およびそれら の合金に由来する回折パターンは検出されず，担体の炭素粒 子によるアモルファス相のみが見られた (Fig. 8).さらに XPSから, 活性点を構成する N, CoおよびIrの存在を確認し， $\mathrm{Co}$ の $2 \mathrm{p}_{3 / 2}$ および $\mathrm{Ir}$ の $4 \mathrm{f}_{7 / 2}$ スペクトルに扔けるケミカルシフ 卜值は，各元素の金属状態 $\left.(\mathrm{Co}: 778.4 \mathrm{eV}, \mathrm{Ir}: 61.1 \mathrm{eV})^{26}\right)$ に対して高エネルギー側ヘシフトしている (Fig. 9). Nの1s スペクトルが約 $400.0 \mathrm{eV}$ に単一ピークとして観測されている ことから, 被覆されたポリピロールの NHに由来する $\mathrm{N}$ 原子 と考えられ21), $\mathrm{N}$ と各金属との電気陰性度 $\left(\chi_{\mathrm{N}}=3.0, \chi_{\mathrm{C}_{0}}=\right.$

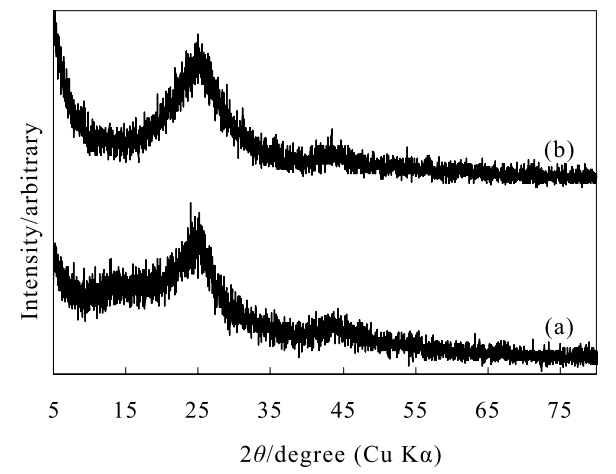

Fig. 8 Powder X-ray diffraction patterns of $\mathrm{Co}+\mathrm{IrPPy} / \mathrm{C}$ before (a) and after (b) heat treatment at $600{ }^{\circ} \mathrm{C}$ under argon atmosphere. Diffraction peaks from amorphous carbon were shown at about $25^{\circ}$ and $40^{\circ}$. 


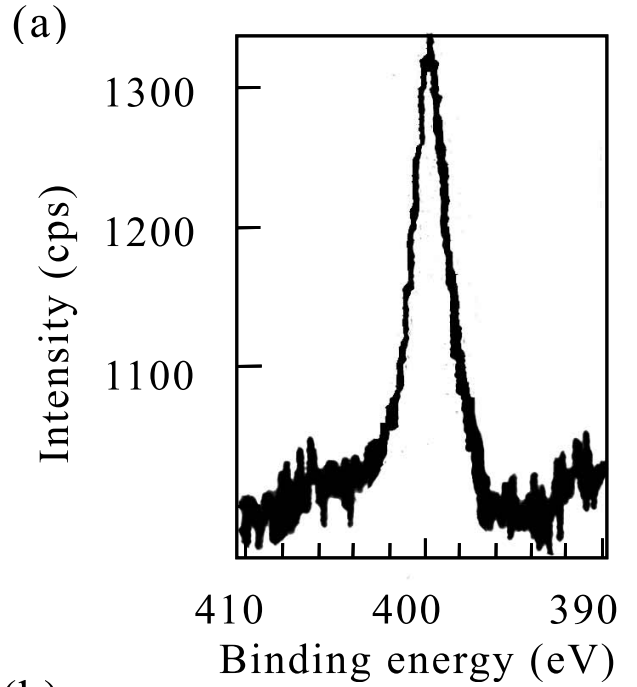

(b)

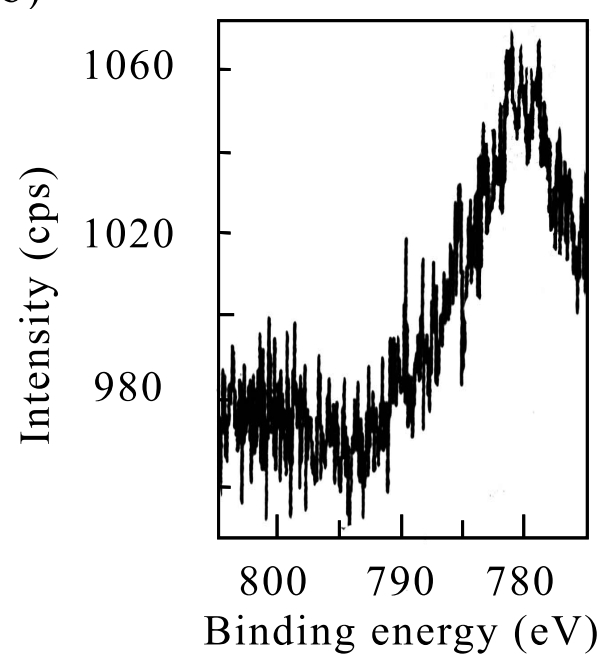

(c)

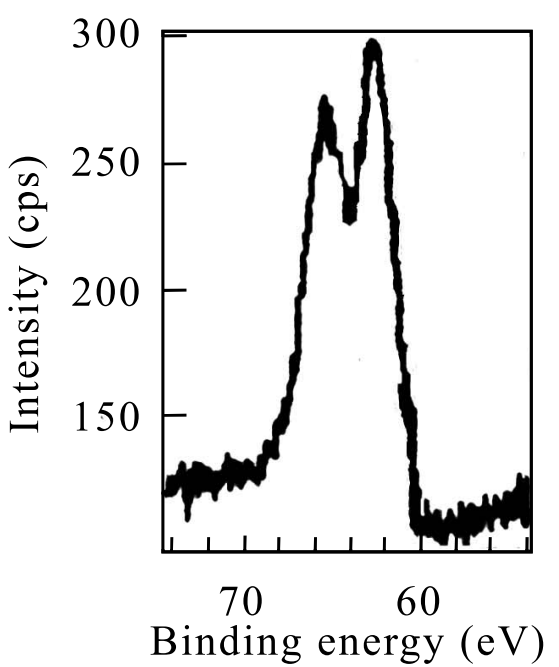

Fig. 9 XPS narrow-scan spectra of (a) N 1s, (b) Co $2 \mathrm{p}_{3 / 2}$, and (c) $\operatorname{Ir} 4 \mathrm{f}_{7 / 2}$ for the Co+IrPPy/C catalyst, showing the presence of nitrogen, cobalt and iridium atoms at the surface of carbon black.

1.8 および $\left.\chi_{\mathrm{Ir}}=2.2\right)$ を考慮すると, 先述のケミカルシフトは 妥当性があり，Co-N および $\mathrm{Ir}-\mathrm{N}$ の結合形成が示唆された。

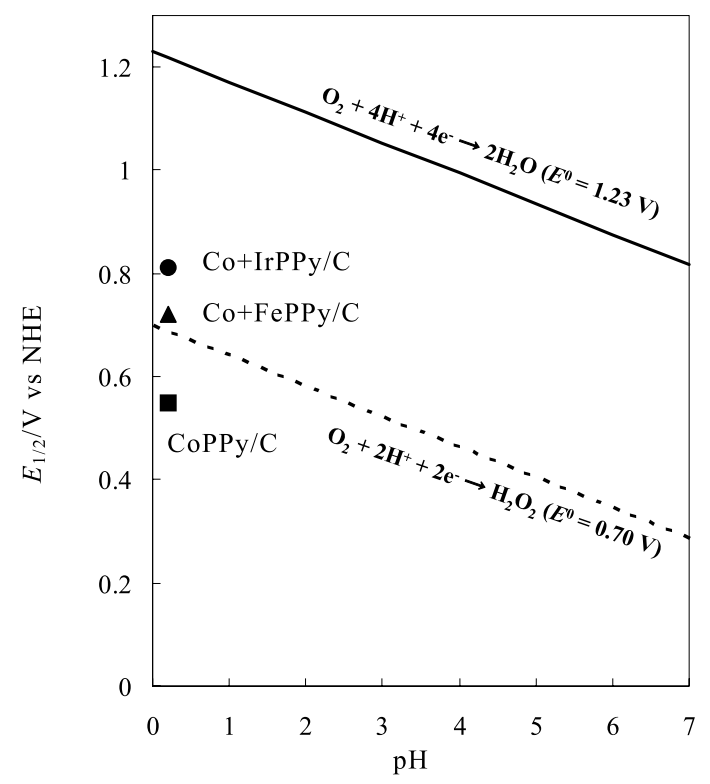

Fig. 10 Comparison of electrocatalytic activities of $\mathrm{Co}+\mathrm{MPPy} / \mathrm{C}$ after heat treatment at optimized temperatures under argon atmosphere for the reduction of $\mathrm{O}_{2}$. Solid lines represented theoretical formal potentials for the reduction of $\mathrm{O}_{2}$ by four electrons $\left(E^{0}=1.23 \mathrm{~V}\right.$ vs NHE) and by two electrons $\left(E^{0}=0.70 \mathrm{~V}\right.$ vs NHE).

特にCoの $2 \mathrm{p}_{3 / 2}$ スペクトルのケミカルシフトに着目すると， 熱処理後では低エネルギー側へシフトしており（782.4から $781.7 \mathrm{eV})$ ，このことから活性点の結合状態の変化が予想さ れ，活性中心の $\mathrm{Co}^{2+}$ における電子密度の向上が見られた. この傾向は既報 ${ }^{21)}$ にある熱処理後の活性点の構造変化と類 似し, 活性点と担体の密着性の向上に伴う電子状態の変化と 考える. 以上の結果から, 熱処理後の著しい酸素還元活性の 向上は高密度化された活性点に起因すると考えられる.

\section{$3.6 \mathrm{Co}+\mathrm{MPPy} / \mathrm{C}$ における酸素還元活性の比較}

本報で調製した Co+MPPy/Cにおける補助金属の複合効果 を，RRDEにおける $E_{1 / 2}$ を抽出して比較することから評価し た. 準静的な条件下 $(\omega=100 \mathrm{rpm})$ で得られる電流一電位 曲線の $E_{1 / 2}$ を, 電解液の $\mathrm{pH}$ に対してプロットすることによ り (Fig. 10), 抵抗分極の小さい条件下で, 触媒の燃料電池 環境下における作動電位を系統的に比較できる。このプロッ 卜が酸素 4 電子還元の熱力学電位（Fig. 10の実線）に近いほ ど, 触媒としての潜在能力が高いことになる. 本報で用いた 各種 $\mathrm{M}^{\mathrm{n}+}$ の導入による酸素還元活性の変化を見てみると, 遷 移金属として $\mathrm{Fe}^{2+}$ を用いた触媒が, 酸素に対して 4 電子還 元触媒として機能していることが分かった（Fig. 10の実線 と破線の間)。一方，貴金属の場合では， $\mathrm{Ir}^{+}$を補助金属に用 いた Co+IrPPy/Cにおいて, 非常に高い電位 $\left(E_{1 / 2}=0.57 \mathrm{~V}\right.$ vs $\mathrm{SCE}$ ) で酸素の 4 電子還元のみが進行しており, \% $\mathrm{H}_{2} \mathrm{O}_{2} \approx$ 0 となった (Table 2). 以上の結果から, 白金フリーの新た なカソード触媒として有用な材料であることが明らかとなっ た。

\section{4 結 論}

導電性高分子であるポリピロールで被覆された炭素粒子に 対し, 従来までのコバルトに加え, 新たに遷移金属および貴 
Table 2 Electrocatalytic activities of $\mathrm{Co}+\mathrm{MPPy} / \mathrm{C}$ for the reduction of $\mathrm{O}_{2}$.

\begin{tabular}{cccccc}
\hline Sample & $\mathrm{M}^{\mathrm{n}+}$ & $\mathrm{Co}^{2+}: \mathrm{M}^{\mathrm{n}+\mathrm{a})}$ & $\begin{array}{c}E_{1 / 2}{ }^{\mathrm{b})} / \mathrm{V} \\
\text { vs SCE }\end{array}$ & $\% \mathrm{H}_{2} \mathrm{O}_{2}{ }^{\mathrm{c})}$ & $\left.n_{\text {av }}{ }^{\mathrm{d}}\right) /-$ \\
\hline $\mathrm{CoPPy} / \mathrm{C}$ & - & - & 0.45 & 32 & 3.4 \\
$\mathrm{Co}+\mathrm{FePPy} / \mathrm{C}$ & $\mathrm{Fe}^{2+}$ & $1.0: 1.3$ & 0.48 & 23 & 3.6 \\
$\mathrm{Co}+\mathrm{IrPPy} / \mathrm{C}$ & $\mathrm{Ir}^{+}$ & $1.0: 1.0$ & 0.57 & 1.5 & 4.0 \\
\hline
\end{tabular}

a) The ratio of loaded metal ions by ED-XRF.

b) Potential for the electroreduction of $\mathrm{O}_{2}$ in current-potential curve at RRDE rotated at $100 \mathrm{rpm}$.

c) Percentage of $\mathrm{H}_{2} \mathrm{O}_{2}$ generated at $\mathrm{RRDE}$ rotated at $100 \mathrm{rpm}$ as estimated by equation (7).

d) Electrons consumed in the reduction of $\mathrm{O}_{2}$ as estimated by equation (8).

金属を導入させた触媒を調製した，触媒調製における金属イ オンの導入比を最適化することで，修飾電極を用いたCVに おける $E_{\mathrm{p}}$ が $\mathrm{CoPPy} / \mathrm{C}$ に対して貴な電位を示し，複合金属に よる効果が示唆された。遷移金属として $\mathrm{Fe}^{2+を}$ を加えた

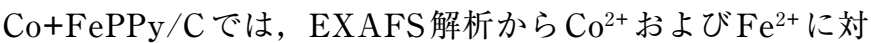
し，4つの窒素原子が配位して $\mathrm{Co}-\mathrm{N}_{4}$ および $\mathrm{M}-\mathrm{N}_{4}$ 構造が形 成されていることを確認し， $R_{\mathrm{Co}-\mathrm{Fe}}$ が約 $3.1 \AA$ 市あることが明 らかになった。最適化した熱処理温度 $\left(650^{\circ} \mathrm{C}\right)$ において, 熱処理した触媒では，RRDEにおける電流-電位曲線から得 られる $E_{1 / 2}$ が $0.48 \mathrm{~V}$ vs SCEに観測され，このとき $n_{\mathrm{av}}=3.6$ を示した.XRDにおいて金属および酸化物等の回折パター ンが観測されず，またXPSにおいて各元素に由来するスぺ クトルが得られたことから, 酸素を架橋配位可能な距離を維 持した状態で炭素粒子表面に $\mathrm{Co}-\mathrm{N}_{4}$ および $\mathrm{M}-\mathrm{N}_{4}$ 構造が存在 し， $\mu$-パーオキソ錯体を経由した酸素 4 電子還元機構が示唆 された。

貴金属に $\mathrm{Ir}^{+}$を用いた Co+IrPPy/Cでは，最適化した熱処 理温度 $\left(600{ }^{\circ} \mathrm{C}\right)$ で処理することで，溶存酸素の還元波が $E_{\mathrm{p}}=0.48 \mathrm{~V}$ vs SCEに観測され，RRDE法から得られる $E_{1 / 2}$ $(=0.57 \mathrm{~V}$ vs SCE $)$ において 4 電子還元反応のみが進行する ことが明らかとなったＸPSおよびXRDにより，金属凝集 や合金化による活性中心の損失は見られず，熱処理後も維持 された錯体構造に起因する酸素還元活性の向上が示された. これらの結果から, 非白金系カソード触媒として有効な材料 に関する知見が得られ，今後はMEAによる分極特性評価や 触媒寿命の検討が急務な課題となる.

\section{文 献}

1) T. Toda, H. Igarashi, and M. Watanabe, J. Electrochem. Soc., 145, 4185 (1998).

2) T. Toda, H. Igarashi, and M. Watanabe, J. Electroanal. Chem., 460, 21 (1999).

3) T. Toda, H. Igarashi, H. Uchida, and M. Watanabe, J. Electrochem. Soc., 146, 3750 (1999).

4) M. Yuasa, A. Yamaguchi, K. Oyaizu, Y. Fujito, M. Kitao, and T. Sato, Polym. Adv. Technol., 16, 702 (2005).

5) J. P. Collman, P. Denisevich, Y. Konai, M. Marrocco, C. Koval, and F. C. Anson, J. Am. Chem. Soc., 102, 6027 (1980).

6) R. R. Durand Jr., C. S. Bencosme, J. P. Collman, and F. C. Anson, J. Am. Chem. Soc., 105, 2710 (1983).

7) R. R. Durand Jr. and F. C. Anson, J. Electroanal. Chem.,
105, 273 (1982).

8) C. K. Chang, H. Y. Liu, and I. Abdalmuhdi, J. Am. Chem. Soc., 106, 2725 (1984).

9) C. -L. Ni, I. Abdalmuhdi, C. K. Chang, and F. C. Anson, J. Phys. Chem., 91, 1158 (1987).

10) C. J. Chang, Y. Deng, A. F. Heyduk, C. K. Chang, and D. G. Nocera, Inorg. Chem., 39, 959 (2000).

11) C. J. Chang, Y. Deng, S. -M. Peng, G. -H. Lee, C. Y. Yeh, and D. G. Nocera, Inorg. Chem., 41, 3008 (2002).

12) L. L. Chang, C. J. Chang, and D. G. Nocera, J. Org. Chem., 68, 4075 (2003).

13) Y. Deng, C. J. Chang, and D. G. Nocera, J. Am. Chem. Soc. 122, 410 (2000).

14) C. J. Chang, Z. -H. Loh, Y. Deng, and D. G. Nocera, Inorg. Chem., 42, 8262 (2003).

15) C. J. Chang, Z. -H. Loh, C. Shi, F. C. Anson, and D. G. Nocera, J. Am. Chem. Soc., 126, 10013 (2004).

16) Z. -H. Loh, S. E. Miller, C. J. Chang, S. D. Carpenter, and D. G. Nocera, J. Phys. Chem. A., 106, 11700 (2002).

17) C. J. Chang, E. A. Barker, B. J. Pistorio, Y. Deng, Z. -H. Loh, and D. G. Nocera, Inorg. Chem., 41, 3102 (2002).

18) J. M. Hodgkiss, C. J. Chang, B. J. Pistorio, and D. G. Nocera, Inorg. Chem., 42, 8270 (2003).

19) B. J. Pistorio, C. J. Chang, and D. G. Nocera, J. Am. Chem. Soc., 124, 7884 (2002).

20) K. Oyaizu and M. Yuasa, Electrochemistry, 73, 1060 (2005) [in Japanese].

21) M. Yuasa, A. Yamaguchi, H. Itsuki, K. Tanaka, M. Yamamoto, and K. Oyaizu, Chem. Mater., 17, 4278 (2005).

22) I. T. Bae, D. A. Tryk, and D. A. Scherson, J. Phys. Chem. B., 102, 4114 (1998).

23) H. Schulenburg, S. Stankov, V. Schünemann, J. Radnik, I. Dorbandt, S. Fiechter, P. Bogdanoff, and H. Tributsch, J. Phys. Chem. B, 107, 9034 (2003).

24) A. J. Bard and L. R. Faulkner, Electrochemical Methods: Fundamentals and Applications $2^{\text {nd }}$ Edition, Wiley, New York (2001).

25) M. Yuasa, K. Oyaizu, A. Yamaguchi, and M. Kuwakado, J. Am. Chem. Soc., 126, 11128 (2004).

26) J. C. Fuggle and N. Mårtensson, J. Electron Spectrosc. Relat. Phenom., 21, 275 (1980).

27) A. L. Bouwkamp-Wijnoltz, W. Visscher, and J. A. R. van Veen, Electrochim. Acta., 39, 1641 (1994).

28) J. P. Collman and K. Kim, J. Am. Chem. Soc., 108, 7847, (1986). 